\author{
SYLWIA SKUBISZ-ŚLUSARCZYK \\ ORCID: 0000-0003-1172-8286 \\ University of Wrocław
}

\title{
COURT EXPERT STATUS IN POLAND. FLAGGING UP SELECTED PROBLEMS
}

\begin{abstract}
The intent of this written presentation is to analyse the multi-faceted issue of the position and functioning of court experts in the Polish legal system. Particular attention should be paid in this respect to the appointment and verification of the competencies of candidates for experts, as well as to the instruments of control over their work. These selected aspects are extremely important, not only from the point of view of public interest, but in particular from the perspective of the party's right to a fair trial, and to have the case heard within a reasonable time. The problems identified and briefly discussed have a structural and systemic nature, and result in arrangements which confirm the necessity for legislative changes proposed for many years, relating to court experts as well as to the practice of judicial authorities. The discussion of these issues has an informative purpose, especially for readers unfamiliar with the Polish legal system.
\end{abstract}

Keywords: court expert, expert status, false opinion, unreliable opinion, late opinion, expert's liability

The current status of a court expert ${ }^{1}$ is governed in a very laconic manner in various legal acts, and, unfortunately, these are not satisfactory and comprehensive regulations. The postulates for changes have been articulated for several decades, with various proposals being brought forward in the form of drafts to change the institution of a court expert. ${ }^{2}$ Discussions on the reform of experts are

${ }^{1}$ Court experts - this term should be understood to include persons registered in the list of court experts representing various specialities.

2 By November 2019, 10 different projects were presented; all ended up in a drawer, including a 2004-2005 draft prepared by the Ministry of Justice in consultation with the court expert community and the Institute of Forensic Research, a 2005 parliamentary draft inspired by the Polish Forensic Association, a government draft prepared by the Ministry of Justice and returned by a parliamentary committee as unconstitutional and contradictory to legal acts (codes), a 2014 draft resulting from the Ministry of Justice committee's work on the assumptions for the court expert law, and a 2018 draft court expert law. At the same time, it should be emphasised that after intensive work and implementation of the EU regulations, i.e. the European Parliament and Council Directive No. 2014/56/ EU of 16 April 2014 and European Parliament and Council Regulation No. 537/2014 of 16 April 2014, in June 2017, the amended Act on Statutory Auditors, Audit Firms and Public Oversight, 
underway, and the analysis of surveillance footage from trials with the participation of court experts proves that changes are necessary. However, before the most urgent changes that should take place in relation to the current state of affairs are flagged, the current status of court experts should be verified.

The institution of court experts in Poland is governed in a dispersed manner and the provisions that regulate this issue can be split into several groups. In the area of political system regulations, there are selected provisions of the Act on the Common Courts System ${ }^{3}$ and the Ordinance of the Minister of Justice on court experts. ${ }^{4}$ This group will also include regulations covering the pursuit of the specified professions, whose representatives may apply to act in the capacity of court experts. ${ }^{5}$ Another group of provisions oscillates around the regulations regarding the use of an expert's opinion, and the rules of disciplining an expert as a participant to the proceedings. In this area, reference should be made to the provisions of the Polish Code of Criminal Proceedings, ${ }^{6}$ the Polish Code of Civil Proceedings ${ }^{7}$ and the Polish Code of Administrative Proceedings. ${ }^{8}$ The above issues are also covered by the provisions of the Ordinance on court experts, as well as in

Journal of Laws 2017, item 1089, as amended by the Act of 19 July 2019 amending the Act on Statutory Auditors, Audit Firms and Public Oversight and certain other acts, Journal of Laws 2019, item 1571 (Ustawa o biegłych rewidentach, firmach audytorskich oraz nadzorze publicznym, Dz.U. 2017, poz. 1089, zmieniona Ustawą z dnia 19 lipca 2019 roku o zmianie ustawy o biegłych rewidentach, firmach audytorskich oraz nadzorze publicznym oraz niektórych innych ustaw, Dz.U. 2019, poz. 1571) came into force.

3 The Act on the Common Courts System of 27 July 2001. Journal of Laws 2001, no. 98, item 1070, as amended (Ustawa Prawo o ustroju sądów powszechnych z dnia 27 lipca 2001 roku. Dz.U. 2001, Nr 98 poz. 1070, z późn. zm.).

4 Ordinance of the Minister of Justice of 24 January 2005 on court experts, Journal of Laws 2005, no. 15, item 133, as amended (Rozporządzenie w sprawie biegłych sądowych z dnia 24 stycznia 2005 roku, Dz.U. 2005, Nr 15, poz. 133, z późn. zm.).

5 Ordinance of the Minister of Health of 27 December 2007 on experts in the field of alcohol addiction. Journal of Laws 2007, no. 250, item 1883, under article 28a of the Act of 26 October 1982 on the upbringing in sobriety and counteracting alcoholism, Journal of Laws 2021, item 1119 (Rozporządzenie Ministra Zdrowia z dnia 27 grudnia 2007 roku w sprawie biegłych w przedmiocie uzależnienia od alkoholu, Dz.U 2007, Nr 250, poz. 1883, na podstawie art. 28a ustawy z dnia 26 października 1982 roku o wychowaniu w trzeźwości i przeciwdziałaniu alkoholizmowi, Dz. U. 2021, poz. 1119).

6 The Polish Code of Criminal Proceedings Act of 6 June 1997. Journal of Laws 1997, no. 89, item 555, as amended (Ustawa Kodeks postępowania karnego z dnia 6 czerwca 1997 roku. Dz.U. 1997, Nr 89, poz. 555, z późn. zm.).

7 The Polish Code of Civil Proceedings Act of 17 November 1964. Journal of Laws 1964, no. 43, item 296, as amended (Ustawa Kodeks postępowania cywilnego z dnia 17 listopada 1964 roku. Dz.U. 1964, Nr 43, poz. 296, z późn. zm.).

8 The Polish Code of Administrative Proceedings Act of 14 June 1960. Journal of Laws 1960, no. 30, item 168, as amended (Ustawa Kodeks postępowania administracyjnego z dnia 14 czerwca 1960 roku. Dz.U. 1960, Nr 30, poz. 168, z późn. zm.). 
the ordinances governing the work of public prosecutors' offices ${ }^{9}$ and courts. ${ }^{10} \mathrm{~T}$ he third group includes the provisions regulating financial issues. They were presented in detail in two Ordinances of the Minister of Justice of April 24, 2013 on fixing the rates of experts' remuneration, lump-sum tariffs, and the manner of documenting expenditure indispensable to issue an opinion in civil proceedings,${ }^{11}$ and on fixing the rates of experts' remuneration, lump-sum tariffs and the manner of documenting expenditure indispensable to issue an opinion in criminal proceedings. ${ }^{12}$

In the absence of a single, complete and unambiguous legal act dedicated to court experts, the controversies which most frequently arise in connection with practice include the following issues: the lack of sufficient verification in the course of registering a person in the list of court experts, the lack of a uniform model for maintaining these lists, and also the issue of the experts' liability for the opinion they prepare, and the matter of their remuneration. It is worth focusing on the selected problems pertaining to the person of a court expert, and define them briefly.

The Ordinance of the Minister of Justice on court experts ${ }^{13}$ is the basic document in which the Polish legislature sets out a detailed procedure for appointing experts, classified under the so-called permanent court experts category, including the experts subject to registration in the list of court experts maintained by the President of a given Regional Court, who is the only entity authorised to appoint experts at a given Court for a five-year term of office. The legislator does not rule out the possibility of appointing an expert for another term. If there are no formal obstacles, the expert may reapply for registration in the list of court experts after the expiry of the five-year term. ${ }^{14}$ More detailed regulations relating

9 Ordinance of the Minister of Justice of 24 March 2010, Regulations on the internal operations of the common organisational entities of the Public Prosecutor's Office, Journal of Laws 2010, no. 49, item 296 (Rozporządzenie Ministra Sprawiedliwości z dnia 24 marca 2010 roku. Regulamin wewnętrznego urzędowania powszechnych jednostek organizacyjnych prokuratury [Dz.U. 2010, $\mathrm{Nr}$ 49, poz. 296]).

10 Ordinance of the Minister of Justice of 18 June 2019. Regulations on the operations of common courts, Journal of Laws 2019, item 1141 (Rozporządzenie Ministra Sprawiedliwości z dnia 18 czerwca 2019 roku. Regulamin urzędowania sądów powszechnych. Dz.U. 2019, poz. 1141).

11 Issued on the basis of the delegation of article 89(5) of the Act of 28 July 2005 on court costs in civil matters (art. 89 ust. 5 ustawy z dnia 28 lipca 2005 roku o kosztach sądowych w sprawach cywilnych).

12 Issued on the basis of the delegation included in article $618 \mathrm{f} \S 5$ of the Polish Code of Criminal Proceedings, Journal of Laws of 2013, item 508 (art. 618f $§ 5$ k.p.k. Dz.U. 2013, poz. 508).

13 Ordinance of the Minister of Justice of 24 January 2005 on court experts, Journal of Laws no. 15, item 133, as amended in 2005, Journal of Laws no. 15, item 133 (Rozporządzenie w sprawie biegłych sądowych z dnia 24 stycznia 2005 roku. Dz.U. nr 15, poz. 133, z późn. zm).

14 Appointment of a court expert at more than one Regional Court is admissible, provided that such an appointment is justified by the interest of the justice system. Where narrow specialities are concerned, such an appointment is necessary in order to ensure assistance to the judicial authorities. The fact of being registered in more than one region must not affect the manner and quality of the work performed by experts. Judgment issued by the Voivodeship Administrative Court (WSA) in Warsaw of 26.06.2007. VI SA/Wa 1549/06 Legalis. 
to the appointment of a person demonstrating special expertise are contained in the procedural laws ${ }^{15}$ which stipulate that in circumstances where such expertise is necessary to clarify a specific issue or even resolve a case, the court may/should consult court experts. This procedure gives the authority an opportunity to consult not only a person registered in the list of court experts, but also a scientific or specialised institution. ${ }^{16}$ In the present case, the Polish Code of Criminal Proceedings, for example, does not introduce any preference for the selection of the opinion-giving entity, leaving the trial body free to decide. In order to complement the picture of the experts category, it should be borne in mind that an authority may appoint a so-called ad-hoc expert, who - although not being registered on the list of court experts - has knowledge of a particular branch of science or demonstrates other skills. ${ }^{17}$

A court expert is usually a person who is present on a list of court experts or performs activities as a member of a scientific or research institution. ${ }^{18}$ However, before this status can be achieved, such a person must make an "effort" to be registered in the list of court experts. The provisions of the said Ordinance on court experts of 2005 set out such registration and the maintenance of lists of court experts by the Presidents of certain Regional Courts. Nevertheless, the very process of verifying a potential candidate's knowledge prior to registration in the list already raises certain reasonable doubts. The President of the Regional Court does not have the means enabling him or her to verify the level of knowledge of a potential candidate for an expert. Without special expertise in a given field of knowledge, the President is not able to assess whether the completion of a particular course or a field of study ensures the appropriate qualifications to be a court expert. Therefore, the preliminary examination of the candidates is only formal, rather than material, in nature. This state of affairs makes it possible to conclude that the substantive preparation of an expert is only verified in the course of the proceedings in which he or she participates. And yet, the reliability of the conducted proceedings and the quality of the opinions presented require that the capacity to

15 Article $193 \S 1$ of the Polish Code of Criminal Proceedings and article $278 \S 1$ of the Polish Code of Civil Proceedings (art. $193 \S 1$ kodeksu postępowania karnego i art. $278 \S 1$ kodeksu postępowania cywilnego).

16 In Poland, these institutions comprise, among others: the Professor Jan Sehn Institute of Forensic Research in Kraków, the Central Forensic Laboratory in Warsaw, the Laboratories of the Voivodeship Police Headquarters, the specified Departments of Higher Education Institutions (Instytut Ekspertyz Sądowych im. Jana Sehna w Krakowie, Centralne Laboratorium Kryminalistyczne w Warszawie, Laboratoria Komend Wojewódzkich Policji).

17 Article 195 of the Polish Code of Criminal Proceedings (art. 195 kodeksu postępowania karnego).

18 Article $193 \S 2 \mathrm{a}$ of the Polish Code of Criminal Code. The provisions relating to court experts shall apply mutatis mutandis to scientific or specialised institutions and to persons who participate in issuing the opinions of such bodies. 
act as an expert should be reserved for persons who give a guarantee of a proper, evidence-based opinion-giving process which is comprehensible to its addressees.

The assessment of court experts' qualifications due to the absence of a uniform system, e.g. a candidate assessment system involving a committee and/or experts, is currently illusory. ${ }^{19}$ In fact, currently, the only solution is to base the selection on presented documents attesting the adequate level of qualification. ${ }^{20}$ Practice shows that the proper verification of the competencies necessary in the area of special expertise extends over a wide range of diverse scientific disciplines, which makes it all the more difficult to assess a candidate's suitability as an expert. The assessment of a contender's skills should be carried out on the basis of the criteria whose formulation would give a zero-one result, i.e. fulfilled, unfulfilled requirements. ${ }^{21}$

With a view to complementing the image of a person - a candidate for an expert - it is worth pointing out the other requirements, which are statutory conditions. We are talking about a standing to bring proceedings for people who are over 25 years of age and enjoy full civil and citizenry rights. In practice, the candidate shall make a declaration that he or she exercises his or her full rights and is not subject to criminal or incapacitation proceedings. The candidate also gives consent to be appointed an expert. A formal requirement is also a guarantee of proper performance of the expert's duties, i.e. some kind of a totality of properties, events and circumstances concerning the opinion-provider, which contributes to his or her image as a person of public trust. The expert must be of good repute. ${ }^{22}$ The required guarantee of proper performance of duties with regard to the experts who apply for registration for a new term of office should be extended to include an assessment of their performance to date. Such a solution seems to be the most appropriate one, as it would make it possible to gather and make accessible the information on individual experts by the entities contracting their opinions. Those details could be used to assess a potential candidate before his or her registration in the list of experts for the subsequent term. ${ }^{23}$ In addition to special expertise, an important determinant of the future expert are the profes-

19 Data published by the Ministry of Justice for the years 2008-2012 indicate that the Presidents of forty-five Regional Courts have very rarely refused to register a person in the list of experts. B. Grabowska et al., Biegli sądowi w Polsce, Raport Helsińskiej Fundacji Praw Człowieka, Warszawa 2014, pp. 16-17.

${ }^{20}$ Relevant certifications, certificates, attestations, diplomas.

21 M. Pękała, P. Rybicki, "Elementy systemu oceny zgodności i ich przydatności do oceny kompetencji biegłych sądowych", [in:] Pozycja i rola bieglego w Polskim systemie prawnym, ed. B. Lewandowski, Warszawa 2016, p. 203. The latest draft Court Expert Act of 2018 does not propose an explicit mechanism for real verification of court expert competencies.

${ }^{22}$ In consequence, a Certificate of a clean criminal record from the National Criminal Register needs to be enclosed. The fact that an expert has been convicted of an offence by a valid and final court judgment brings about a situation where the expert does not meet the basic condition for being an expert.

${ }^{23}$ M. Pękała, P. Rybicki, op. cit., pp. 206-207. 
sional qualifications, complemented by appropriate practical experience. ${ }^{24}$ This is an absolute prerequisite, since without having specialist knowledge in a particular branch of science, arts, etc., appointment of a court expert will be impossible.

The assessment of all documents submitted by the candidate is the responsibility of the President of the Regional Court, who is obliged to assess the professional qualifications of the future expert without the knowledge of the specific character of the speciality in which the person is to be appointed as an expert. ${ }^{25}$

A recapitulation of the above requirements for persons who present their candidacy for the expert's position should take into account certain additional - and no less important - elements which, at present, are unfortunately overlooked and not reflected in legal regulations. Both the candidate for an expert and an appointed court expert should provide the testing and analysis methods they use, which comply with the determined criteria for the evaluation of scientific evidence for the purposes of the justice system. On this basis, it will be possible to unambiguously verify the area of special expertise and assign them to the developed register of sciences and scientific disciplines. In addition, court experts should be bound by an obligation of continuous professional development which would be evaluated on a periodic basis. On the other hand, information on the fulfilment of the essential and additional requirements by each expert should be made public to the persons concerned as facts and recommendations. ${ }^{26}$

The Presidents of Regional Courts are obliged to keep lists and registers ${ }^{27}$ of court experts on the data sheets opened for each expert. The regulation referred to in $\S 8$ of the Ordinance on court experts is fragmented in nature, as there is no uniform model for the maintenance of lists. Obviously, numerous courts have adopted a certain pattern of making entries as part of two separated basic categories of sciences: technical (or other) sciences and medical sciences. ${ }^{28}$ Given the lack of unambiguous legal regulations, which also serve as the guidelines for maintaining the above mentioned lists, there are considerable discrepancies in their technical structure. Consequently, the heterogeneous character of the lists leads to many misunderstandings; for example, regarding the correct and detailed

${ }^{24}$ In the regulations, there are no detailed guidelines on the period of experience required.

25 K. Flaga-Gieruszyńska, Biegły w postępowaniu cywilnym i karnym. Komentarz praktyczny $z$ orzecznictwem. Wzory pism procesowych i orzeczeń, Warszawa 2018, pp. 232-233. In addition to the professional competencies, the candidate's social competencies are also important, especially in the field of interpersonal communication. These so-called soft skills, i.e. communication skills and the ability to present opinions in a logical, clear and comprehensible way, are also elements which testify to the abilities and predispositions of an expert.

26 M. Pękała, P. Rybicki, op. cit., p. 207.

27 The lists provide the address of the expert, the expiry date until which the expert has been appointed, and other details of the specialisation he or she represents.

${ }^{28}$ In view of the need to present these lists to the Minister of Justice, it seems appropriate to develop a central catalogue of court experts. 
specification and publication of the court experts' speciality. ${ }^{29}$ These issues should be phrased as precisely as possible to allow the contracting authority to select the most appropriate expert to draft the opinion. This state could result in eliminating situations where the identification of an expert's competencies would be extremely burdensome, especially in cases of narrow specialities. ${ }^{30}$

Lists of court experts may be and are made available by Presidents of Regional Courts to specific persons, i.e. in particular to parties, participants to the proceedings and authorities conducting the proceedings. For each expert, data sheets are maintained as internal (judicial) "record keeping devices" containing the same information as the information provided on the list of experts. The aim of these measures is to maintain the openness and public availability of the lists of court experts so as to enable the parties concerned to identify experts in a particular field, speciality ${ }^{31}$ in the long-term perspective. Information established on the basis of the data - or the lack thereof - recorded on the lists of court experts may indicate that a person has been removed from the list. The prerequisites for removal from the list of court experts are clearly laid out in the discussed provisions of the Ordinance. The reasons are as follows: dismissal of the expert from office, death of the expert, and expiry of the period for which he or she was appointed (unless the appointment has been renewed). Strangely enough, the legislator does not refer to the possible suspension of an expert in the performance of his or her duties $^{32}$, which is clearly legislative negligence.

In the current picture, the assessment of competencies as well as the outline of an unambiguous expert's status is extremely succinct and ambiguous, and raises a lot of misunderstandings and objections of formal, procedural and substantive nature. Thus, the perspective of the expert's licence as a person providing certain "services" and their liability for the submitted opinion does not encourage optimism. Consequently, it would be appropriate to propose a comprehensive regulation of the status of court experts, replacing the current legal acts. It is also neces-

29 A review of the current lists of court experts made available by the individual Regional Courts shows complete freedom, both in the use of the nomenclature and the systematics of individual areas of skills. Creating a register in relation to such data is unfeasible. One of the many reasons for this state of affairs is that the presidents of the Regional Courts uncritically accept the specialities provided by experts, that have exceptional and unique names, unique character, or the ones in which individual persons are specialised. Such activities miss the determined purpose.

${ }^{30}$ K. Flaga-Gieruszyńska, op. cit., pp. 250-251. Communication on the register of court experts of 19 October 1994. Journal of Laws no. 5, item 30 (Komunikat w sprawie wykazu biegłych sądowych z dnia 19 października 1994 roku Dz.Urz. Ms Nr 5, poz. 30) in which the Ministry of Justice made public the register of court experts appointed for occasional or rare specialities - status as at 1.09.1994. In one hundred distinguished specialisations, 1413 experts were listed. The validity of such a list should be reconsidered, as the progressive development in many areas of life has led to greater specialisation in science, technology, crafts, etc.

31 K. Flaga-Gieruszyńska, op. cit., 251-252.

32 The notes concerning the suspension of an expert in the pursued activities are frequently provided on lists and data sheets. 
sary to increase the substantive requirements for candidates for court experts, as well as to create mechanisms for the effective recruitment of competent candidates for court experts.

In order to ensure - in the current state of the law - some kind of control over the expert and directly over his or her "work", the legislator has introduced restrictions on the entitlement to court expert fees. The possibility of granting expert fees in the circumstances of a false opinion being drafted and submitted has been categorically excluded. This restriction also excludes reimbursement of any costs incurred in the course of the opinion-giving process. As a second case, the legislator sanctioned the possibility to limit the amount of remuneration in the case of an unreliable opinion or an opinion being prepared with significant unjustified delay. ${ }^{33}$

The introduced solutions are a certain form of repressions aimed at eliminating the negative practice of drafting judicial opinions, which consists of an expert failing to comply with the time-limits for drawing up an opinion, set by the trial body, or in drawing up laconic, incomplete opinions. They can also be considered as instruments obliging court experts to give their informed consent to the preparation and presentation of an opinion. ${ }^{34}$

In connection with the legislator's assumptions restricting or excluding the remuneration received by a court expert, the following terms: false opinion, unreliable and late opinion, should be clarified and briefly discussed. The objective of clarifying the above issues is also related to the liability incurred by court ex-

33 The matters related to remuneration were governed in: article 288 of Polish Code of Civil Proceedings; in the Ordinance of the Minister of Justice of 24 April 2013 on determining the rates of experts' remuneration, lump-sum tariffs, and the manner of documenting expenditure indispensable to issue an opinion in civil proceedings (Journal of Laws 2013, item 518, as amended); in the Ordinance of the Minister of Justice of 24 April 2013 and on determining the rates of experts' remuneration, lump-sum tariffs and the manner of documenting expenditure indispensable to issue an opinion in criminal proceedings (Journal of Laws 2013, item 508, as amended): Ordinance of the Minister of Justice of 18 December 1975 on the costs of taking evidence based on expert opinion in court proceedings (Journal of Laws no. 46, item 254, as amended) (Kodeks postępowania cywilnego art. 288; Rozporządzeniu Ministra Sprawiedliwości z dnia 24 kwietnia 2013 roku w sprawie określenia stawek wynagrodzenia biegłych, taryf zryczałtowanych oraz sposobu dokumentowania wydatków niezbędnych dla wydania opinii w postępowaniu cywilnym [Dz.U. 2013, poz. 518, z późn. zm]; Rozporządzeniu Ministra Sprawiedliwości z dnia 24 kwietnia 2013 roku w sprawie określenia stawek wynagrodzenia biegłych, taryf zryczałtowanych oraz sposobu dokumentowania wydatków niezbędnych dla wydania opinii w postępowaniu karnym [Dz.U. 2013, poz. 508 z późn. zm.]: Rozporządzeniu Ministra Sprawiedliwości z dnia 18 grudnia 1975 roku w sprawie kosztów przeprowadzenia dowodu z opinii biegłych w postępowaniu sądowym (Dz.U. 1975, Nr 46, poz. 254 z późn. zm.]).

34 Awareness is related to the optional refusal of the obligation imposed on an expert and arises from reasons which entitle the witness to refuse to testify, or from an obstacle which makes it impossible to give an opinion. 
perts. However, following the order of the undertaken elements, one should begin with an unambiguous definition of the indicated concepts.

A false opinion is a document in which the expert presents untrue or fictitious facts and statements, and an opinion in which he or she intentionally omits and conceals data and circumstances of relevant importance to the opinion. An expert can commit an offence by acting (presenting untrue facts) or by omission (concealing facts). If that is the case, the authority may have to handle a false opinion by way of confirming the untruth or concealing it. A false opinion occurs when an expert acts intentionally, i.e. deliberately omits, conceals certain facts and circumstances or invokes a fictitious study or his or her own experience that is not reflected in reality. ${ }^{35}$

From the perspective of the provisions of the Polish Criminal Code, the regulations on false opinions additionally set out the issue of court experts' liability. ${ }^{36}$ The rules apply the criterion of truth vis-a-vis the expert's opinion, which may give rise to some concern, since it arises from the nature of this documentary evidence that it is intended to be the opinion prepared by a person demonstrating specialist knowledge. On the contrary, a false opinion may be said to exist when the facts and circumstances underlying the claims and conclusions contained therein are contrary to reality or when the adopted research method is erroneous in nature. The regulation implemented by the legislator is intended to increase the level of protection of the justice system against misleading the trial bodies. Due to the exposure of the public interest to significant damage, the legislator took such drastic steps involving an increase in the upper limit of criminal liability (up to 10 years of deprivation of liberty). ${ }^{37}$

However, it is the modification introduced by article $233 \S 4 \mathrm{a}^{38}$ of the Polish Criminal Code that is more debatable, since doubts arise as to the legitimacy of the provision introducing criminal liability for the privileged type of a prohibited act that was committed unintentionally. The rationale for introducing such a regulation is to criminalise activities that counteract the practice of submitting

35 An opinion which is presented by an expert and which contains irregularities due to insufficient knowledge or professional experience, or committed by recklessness or negligence, is not a false opinion. K. Flaga-Gieruszyńska, op. cit., pp. 194-195.

36 Provision of the Polish Criminal Code, article $233 \S 4$, Whoever, acting as an expert, surveyor or translator, provides a false opinion, expert study or translation intended to be used as evidence in proceedings, shall be subject to the penalty of deprivation of liberty for between 1 year and 10 years.

37 M. Nowak, "Wątpliwości związane z odpowiedzialnością prawną biegłego sądowego w świetle znowelizowanego art. 233 § 4A Kodeksu Karnego", Zeszyty Prawnicze 17.2, 2017, pp. $75-76$.

38 Article $233 \S 4 \mathrm{a}$ of the Polish Criminal Code, if the perpetrator of the act set out in $\S 4$ acts unintentionally, exposing the public interest to a risk, he/she is subject to a penalty of deprivation of liberty for up to 3 years. 
unreliable opinions, including those provided by private experts. ${ }^{39}$ However, taking into account the exegesis of the analysed solutions, punishability of unintentional submission of a false opinion should be considered misguided. The word false may suggest wilfulness in the preparation of the opinion, and recklessness or negligence during its submission. ${ }^{40}$

It should be noted that in addition to the criminal liability referred to above, there is also experts' civil liability. ${ }^{41}$ Two opposing viewpoints can be distinguished with regard to civil liability. The fact that this is an authority which contracts the issue of an opinion does not mean that it accepts liability towards third parties. The expert is independent in giving an opinion, understood as an expression of his or her own views on a particular matter, and it is irrelevant that the expert follows the guidelines arising from the scope of the expert opinion, that scope being determined by the authority. The fact that the expert draws up an opinion on the basis of the case files does not prejudge his or her lack of independence, as at this point there is no transfer of liability for the results of his or her actions to the court. ${ }^{42}$ The other standpoint presents a completely different perspective, according to which an expert, in the performance of his or her duties, is subject to the trial body which is the decision-maker of all actions taken and is thus responsible for damage through the fault of that person when entrusting him or her with the performance of his or her duties. It is the State Treasury which bears responsibility for the actions taken in order to give the opinion and to admit it as evidence. And in the above state, it is the State Treasury that is responsible for the damage caused by a defective expert opinion. ${ }^{43}$ To complement the reasoning on the lia-

39 The amendments to article $393 \S 3$ of the Code of Criminal Proceedings introduced as of 1 July 2015 enable the Court to admit an extrajudicial opinion and to include it among the evidence which constitute the basis for passing judgments. An expert on the list of court experts may issue a private opinion, which is a document prepared at the request of a litigant. See: J. Dzierżanowska, J. Studzińska, Biegli w postepowaniu sadowym cywilnym i karnym. Praktyczne omówienie regulacji z orzecznictwem, Komentarze problemowe, Warszawa 2019, pp. 398-403. On the grounds of the Polish Code of Civil Proceedings, private opinions cannot be treated on a par with court expert opinions and cannot replace them, article $278 \S 1$. On the contrary, article $278^{1}$ provides for the possibility of admitting evidence based on an opinion drawn up at the request of a public authority in other proceedings provided for by law.

40 A. Grześkowiak, K. Wiak, “Art. 233”, [in:] Kodeks Karny. Komentarz, Legalis, Warsaw 2019.

41 Opinions are split on this subject, and two different standpoints are distinguished in the doctrine. Judgement issued by the Polish Constitutional Tribunal of 12 June 2008. (K 50/50) in the case regarding the status of the court expert in the context of the Goods and Services Tax.

42 The presented standpoint was approved by the Supreme Court in the judgment of 29 May 2015 (V CSK 479/14). A similar opinion was presented the Appellate Court in Warsaw in the Judgement of 3 November 2016 (I ACa 1767/15).

43 P. Żelek, Odpowiedzialność prawna biegłych sądowych? Czy bycie biegłym jest ryzykowne? http://katalizatortechnologii.pl/odpowiedzialnosc-prawna-bieglych-sadowych-czy-bycie-bieglymjest-ryzykowne/ (accessed: 2.11.2019). 
bility of experts, the so-called expert liability for breach of order, which results in a fine, arrest or forced bringing applied in the event of persistent evasion from the expert's activities, ${ }^{44}$ is worth noting. Given the duties of experts and the performance of their tasks, undoubtedly the rules on their liability take on particular significance. On the one hand, the justice system must have access to professionals of various specialities who, owing to their knowledge, skills and experience, will allow the court to become acquainted with a certain fragment of reality in detail, and on the other hand, the regulations concerning the liability of experts cannot constitute some kind of "stiff corset" which will effectively deter potential candidates from taking up the duties of an expert. Excessive liberalisation of the rules on the liability of experts poses a risks of appointing unreliable persons, while too far-reaching restrictions may result in few experts taking the trouble to undertake the opinion-giving process. ${ }^{45}$ Such concerns are already being expressed by medical experts, and some of them consider abandoning their litigation activities as experts in order not to take unnecessary risk in the face of unclear legal regulations. ${ }^{46}$ Coming back to the central topic, which aims to explain the concepts, it is worth referring to the category of an unreliable opinion. It is obvious that an expert opinion should have a high level of reliability and objectivity with regard to the subject-matter of the opinion, ${ }^{47}$ yet this is not always the case, as sometimes the opinion is drafted in such a way that its transparency, comprehensibility and persuasiveness leaves a lot to be desired. In addition, an unreliable opinion is most often drafted in a laconic and too vague manner with regard to the subject matter of the opinion. This is the case when the opinion provider omits or excessively restricts the main part of the opinion, i.e. he or she fails to provide a description of the study methods used and applied, as well as the final conclusions. The consequence of an unreliable opinion may be the need for a supplementary opinion. When dealing with unreliable opinions, it is possible to indicate the reasons why a given opinion is considered insufficient; these are the circumstances where: the expert does not express an opinion on the issues specified by the authority, the opinion does not contain a reasoning, the opinion or the reasoning is unclear, incomplete, internally or externally contradictory, there is a discrepancy between experts. When assessing the reliability of the presented court opinion, the authority should take into account the elements related to the opinion-provider's compli-

44 Article $287 \S 1$ and 2 read in conjunction with article $285 \S 1$ of the Polish Code of Criminal Proceedings, article 287 of the Polish Code of Civil Proceedings, article $88 \S 1$ of the Polish Code of Administrative Proceedings. The criminal and civil procedure provide for a possibility of charging an expert with the costs of the proceedings, article $189 \S 1$ of the Polish Code of Criminal Proceedings and article 110 of the Polish Code of Civil Proceedings.

45 P. Żelek, op. cit.

46 M. Nowak, op. cit., p. 98.

47 There are no control procedures aimed at checking the reliability of an opinion. J. Dzierżanowska, J. Studzińska, "Kryteria oceny dowodu z opinii biegłego w orzecznictwie sadów powszechnych i Sądu Najwyższego", Roczniki Nauk Prawnych XXV, 2015, no. 2, pp. 30-31. 
ance with the requirements relating to: the qualifications they hold, their impartial activity, the use of materials on which their conclusions were based, the correctness of the performed activities, the adequacy of the applied research methods, the consistency of the answers given, the logic of the reasoning for the opinion. ${ }^{48}$

The requirement for the reliability of an opinion, and, in more detail, one of the elements which are components of that solidity, was the subject-matter of dynamic changes undertaken by the amendment to the Polish Code of Criminal Procedure of 2019. This regards the right to make the case files available to the expert to the extent necessary for the expert to issue an opinion. ${ }^{49}$ The amended wording of article $198 \S 1$ is intended to counteract the practice of making the files available to the expert in each case before he or she draws up the opinion, particularly where becoming acquainted with the contents of a previous opinion may be suggestive for drawing up the current opinion. An exception substantiating a newly-appointed expert acquainting himself or herself with the previous opinion is the situation where the subject matter of the new opinion relates directly to the content of the previous opinion given in the case. The solution offered by the Code in this respect is based on a compromise, allowing documents from the case files, or their certified copies, to be made available to experts in exceptional cases where this is necessary for the opinion-giving process, thus limiting the scope of access. ${ }^{50}$

On the ground of the conducted considerations, it is worth briefly raising and flagging one more element, namely the unreliability of an opinion, which cannot be equated with its falseness. The assessment carried out by the trial body of whether an opinion has been drafted in a reliable way will relate primarily to its content, the manner in which it was analysed and the conclusions drawn. Nevertheless, the aspect of unreliability can be understood as one of the manifestations of a false opinion in the context of deliberations conducted from the standpoint of judicature and the doctrine of law. It can be difficult to distinguish between an erroneous, unclear, incomplete or unintentionally false opinion. Such a situation may give rise to concerns that experts whose opinions do not meet the expectations of the authorities in charge of the proceedings will be prosecuted, and that would be an extremely uncomfortable situation..$^{51}$

An opinion drafted to the exclusion of the time-limits set by the trial body results in it being late. This situation is not desirable from the point of view of the postulate to conduct the proceedings in a speedy and efficient manner. The efficiency of the pending proceedings is a prerequisite for a reliable handling

48 See more: T. Tomaszewski, Dowód z opinii biegłego w postępowaniu karnym, Kraków 2000, pp. 76-77.

49 Amendment to article $198 \S 1$ of the Polish Code of Criminal Proceedings. The Act of 19 July 2019 on the amendment to the Act - the Polish Code of Criminal Proceedings and certain other Acts. Journal of Laws 2019, item 1694. Article 284 of the Polish Code of Civil Proceedings.

50 J. Dzierżanowska, J. Studzińska, op. cit., p. 338.

51 R. Stefański, “Art. 233”, [in:] Kodeks Karny. Komentarz, Legalis, Warszawa 2018. 
of the case. For this reason, the legislator has provided for two mechanisms under the provisions of the Polish Code of Civil Proceedings which constitute formal control over a court expert. ${ }^{52}$ The court shall impose a fine on the expert for an unjustified delay in the submission of the opinion. Another mechanism provides for the possible proportional reduction in remuneration where an opinion is submitted with a significant, unjustified delay. The obligation for court experts to draft and present their opinions in a timely manner is intended to ensure that parties exercise the right to have their case heard within a reasonable timeframe. ${ }^{53}$

There is no doubt that in the modern world, the opinions of specialists in various fields presented in the form of evidence based on an expert opinion are extremely important for the results of court proceedings. That is why it seems so relevant that the persons taking decisions on who can act as an expert in a case should pay attention to the substantive and practical aspects of the candidate's preparedness to serve this function. However, the fulfilment of the prerequisite of substantive preparation does not exempt the trial body from reviewing the evidence based on an expert opinion. The expert opinion is subject to evaluation by both the trial bodies and the parties. For the assessment to be factual, it requires to have a clear picture of the fundamental issues related to the subject-matter of the opinion. The normative basis for the assessment of an expert opinion is formed by the provisions of the Polish Code of Criminal Proceedings, article 201 (read in conjunction with article 7 and $193 \S 1$ ), and the provisions of the Polish Code of Civil Proceedings, article $233 \S 1$. Like any other evidence, an opinion is subject to free evaluation, with such evaluation being not only the right, but also the duty of the trial body. Bearing in mind the judgments issued by the Polish Supreme Court ${ }^{54}$ and by common courts, ${ }^{55}$ relating to evidence based on an expert opinion, it is possible to identify those which lay down the criteria for the assessment of evidence. The most frequently indicated assumptions are: requirements of contemporary knowledge, compliance with the principles of logic, methodological impeccability of the method, assessment of the expert's knowledge, competencies and reliability, completeness, fullness, and clarity of the opinion, preparation of the opinion according to unified standards with regard to the attestation of the laboratory. ${ }^{56}$

52 Article 287 and 285 of the Polish Code of Civil Proceedings.

53 K. Flaga-Gieruszyńska, op. cit., p. 198.

54 Among others, Judgment issued by the Polish Supreme Court: of 30.01.1974, IIKR 194/73, LEX no. 21611, and of 12.10.2006, IVKK 236/06 OSNwSK 2006/1, item 1958; Judgment issued by the Polish Supreme Court of 14.11.2013, IVCSK 135/13, LEX no. 1405234; Judgment issued by the Polish Supreme Court of 27.11.1996, I CKU 27/96, LEX no. 50561.

55 Among others, Judgment issued by the Appellate Court in Szczecin of 23.07.2014, III AUa 462/13, LEX no. 1527191; Judgement issued by the Appellate Court in Katowice of 27.07.2017, II AKa 269/17, LEX no. 2420921.

56 J. Dzierżanowska, J. Studzińska, op. cit., pp. 72-282 and 426-434. 
These words by Locard remain valid: "the investigating or adjudicating judge, standing at an appropriate level, must be able to skilfully read - admittedly rather than to prepare - all the details of the expert examination, and not the conclusions, and must be able to assess the expert examination as a whole, as well as to recognise its importance and value". ${ }^{57}$

In the context of the information presented above, which undoubtedly form only part of a more complex problem, it is worthwhile to briefly sum up the position of the court expert in Poland. The assessment of the current legal status of experts and verification of their competencies has been and is the subject-matter of many analyses and consultations which have resulted in a joint report on the state of court experts in Poland in cooperation with the Polish Business Roundtable and the Helsinki Foundation for Human Rights. ${ }^{58}$ Numerous observations are also contained in the information on the results of the audit carried out by the Supreme Audit Office and the report entitled "Assessment of the Competencies of Court Experts. Expectations and Recommendations", published by the European Forensic Initiatives Centre (EFIC) Foundation. ${ }^{59}$

The conclusion against the background of the cited documents is unambiguous; the role of experts in the pending proceedings is important enough for their status to be precisely regulated in the law. The functioning of the institution of the court expert should be refined so that it is not a source of emerging irregularities of the administration of justice. ${ }^{60}$ Unfortunately, the current status quo does not provide such a guarantee, and the systemic control of both the candidates for court experts and the quality of court experts' work is illusive. In order to create a mechanism for verifying the competencies of persons who are supposed to act as court experts, an attempt should be made to identify the desirable qualities which the so-called candidates for court experts should possess. Such findings will enable the selection of appropriate tools for the evaluation of candidates. Obviously, the "control" instruments should meet the expectations of the legal community and trial bodies. It may be worthwhile to take into account different criteria and systems for such control that emerge around the world when creating a "control mechanism". ${ }^{61}$ Bearing in mind the various solutions, which — incidentally — appear in a similar form in many countries, it is worth proposing a kind of data-

57 E. Locard, Dochodzenie przestępstw wedtug metod naukowych, Łódź 1937, p. 261; J. Dzierżanowska, J. Studzińska, op. cit., p. 431.

58 http://beta.hfhr.pl/wp-content/uploads/2014/04/HFPC_PRB_biegli-sądowi_w_polsce.pdf (accessed: 3.11.2019).

59 https://www.nik.gov.pl/aktualnosci/nik-o-bieglych-w-wymiarze-sprawiedliwosci.html (accessed: 3.11.2019).

$60 \mathrm{http}: / /$ forensicwatch.pl/ (accessed: 12.03.2020).

61 Assessments of competencies of court experts and the quality of their work performed in different countries. See more in: Kompetencje biegłych sadowych - oczekiwania i kryteria oceny, przeglą rozwiazań stosowanych $w$ różnych państwach i systemach prawnych, Forensic Watch Project (no. E2/2162), http://forensicwatch.pl/ (accessed: 12.03.2020). 
base $^{62}$ which will contain the most important requirements for court expert candidates, and those relating to their control. This will make it possible to formulate the basic assumptions of the future law on court experts, which will be a systemic legal regulation relating to court experts, and the rules for their appointment, replacing the current legal acts. The so-called "wish list" should include: maintaining the independence of court experts and the freedom of trial bodies in the selection of experts for certain cases, increasing the substantive requirements for court expert candidates, proposing mechanisms for the effective recruitment of competent experts, appropriate structuring of the criminal liability of experts for submitting a false opinion, the development of a new system of remuneration for experts, and an obligation for experts to constantly improve their qualifications. The future law on court experts should be prepared according to the procedures of a democratic state of law, taking into account the requirements indicated above, which will be prepared in consultation and in cooperation with the court expert community. Recommendations on the standardisation of the quality requirements for expert opinions may not be omitted, either. ${ }^{63}$

An important aspect of the quality of opinion-giving is the accreditation and certification of testing laboratories. According to international standards, accreditation equals the issue of a statement that demonstrates compliance with explicitly defined requirements of a laboratory that is competent to perform the tests specified in the scope of test accreditation. On the other hand, the certificate is the result of successfully completed accreditation. ${ }^{64}$ The implementation of a quality system allows forensic laboratories to provide services in the best possible way and to offer a guarantee of credibility of the prepared opinions. Such activities strengthen the position of the research institution, especially when the analysis is performed according to established procedures and their results are reported with a high degree of accuracy. With regard to forensic laboratories, the application of the EN ISO/IEC $17025^{65}$ standard is recommended within the European Union. It seems to be an absolute minimum that the laboratory which will perform forensic examinations should be accredited ${ }^{66}$ and certified. Talking about

62 An attempt to create such a database was made after the research project "Forensic Watch" was completed (no. E2/2162), and it includes: formal requirements for experts, substantive competencies, communication skills and ethical issues.

63 The Polish Code of Criminal Proceedings and the Ordinance of the Minister of Justice of 24 January 2005 on court experts (Rozporządzenie Ministra Sprawiedliwości z 24 stycznia 2005 roku w sprawie biegłych sądowych) do not oblige trial bodies, to take into account - when admitting evidence based on an expert opinion - appropriate quality standards of an opinion, confirming high qualifications of an expert or a scientific or specialised institution, based on transparent certification and accreditation procedures. J. Dzierżanowska, J. Studzińska, op. cit., p. 415.

64 P. Girdwoyń, Opinia biegłego w sprawach karnych europejskim systemie prawnym. Perspektywy harmonizacji, Warszawa 2011, p. 108.

65 The said standard lays down general requirements for testing and calibration laboratories.

66 Accreditation in Poland is granted by the Polish Centre for Accreditation. In 2005, the Centre granted accreditation for all submitted testing methods to the Central Police Research Laboratory. 
the quality of opinions, one should bear in mind the actions leading to the standardisation of forensic science procedures within the European Union. The creation of a European Forensic Science Area is aimed at clarifying common principles for the development of good practices for forensic laboratories in Europe and common minimum requirements for staff competencies. ${ }^{67}$ High quality of evidence based on expert opinions is also to be ensured by initiatives taken by the expert community, e.g. in the form of active organisations such as: European Network of Forensic Science Institutes ${ }^{68}$ and EuroExpert. ${ }^{69}$ It should be remembered that the quality of an opinion depends on the knowledge, preparation and work ethic partly of all those involved in resolution of the case.

An input in the discussion can be a case study showing the importance of the discussed problem and, at the same time, the need for a proposal of a comprehensive legal regulation concerning the status of court experts in Poland.

As part of the pending criminal proceedings, two brothers (aged 19 and 24) were accused under article $200 \S 1$ of the Polish Criminal Code (sexual intercourse with a minor), read in conjunction with article $217 \S 1$ (breach of personal inviolability) of the Polish Criminal Code. The mother of the boys was also accused of the act set out in article $207 \S 1$ (physical and mental abuse). In the public prosecutor's opinion, the men committed, among others, offenses of sexual intercourse and other sexual activity towards their stepsister (the minor was about two years old). The notification of a suspected criminal offence committed to the detriment of a minor was submitted by Bernadeta X., who, at the time of the submission, was an expert in the field of sexual offences registered in the list maintained by the President of the Regional Court in Olsztyn. The bill of indictment was mainly based on the testimony of the notifying party, who conducted private psychotherapy with the minor victim, and on the testimony of the girl's surrogate mother, to whom the child was supposed to reveal the information about the criminal activities of her step-brothers. The interrogation of the minor before the court took place when the child was three years old; the testimony was laconic and unclear, which was justified by her age and by the fact that conversations concerning the alleged experience of sexual violence had previously taken place. At the time

The Laboratory of the Warsaw Police Headquarters and the Institute of Forensic Research in Kraków also meet the requirements of the PN-EN ISO/IEC 17025-2005 standard.

${ }^{67}$ Justice and Home Affairs Council, Brussels 13.12.2011. http://www.consilium.europa.eu (accessed: 12.03.2020).

68 The Network of Institutes operates in accordance with the adopted ENFSI Constitution which introduces, among other things, good laboratory practices and international standards to ensure the quality of research and the competencies of those who perform it. A. Filewicz, "ENFSI a perspektywy rozwoju kryminalistyki. Rola i znaczenie organizacji na arenie międzynarodowej”, Problemy Kryminalistyki 2003, no. 3, p. 6 f.

69 The organisation has developed a Code of Practice which indicates the duties of court experts, guidance on opinion-making, and minimum standards for the content of an expert opinion. P. Girdwoyń, Opinia biegłego w sprawach karnych..., op. cit., pp. 106-107. 
the bill of indictment was brought to the court, there was evidence which fundamentally challenged the public prosecutor's thesis about the perpetration and guilt of the minor's brothers. In particular, they included the paediatrician's testimony, which unambiguously indicated that there were no physiognomic signs of breach of the girl's inviolability, or other injuries. The evidence admitted by the court at the request of the defence counsel confirmed significant doubts as to the occurrence of criminal behaviour.

During the main trial, Bernadeta X. gave testimony in the capacity of a witness. The woman presented the thesis that the girl was a victim of sexual violence. In her arguments, she relied on her authority as a court expert in the field of sexual offences and on the fact that she had given numerous opinions on cases in this area. Asked in more detail by the defence counsel, the expert revealed a lot of information about her competencies and the documents obtained to prove her special knowledge. She indicated that she was a pedagogue running a therapeutic office, that she had been awarded a certificate by the Polish Sexual Association in Warsaw, that she was vice-president of the Polish Sexual Association in Warsaw, and that the President of the Regional Court in Olsztyn confirmed her knowledge by appointing her an expert on the list of court experts. Nevertheless, the defence counsel grew suspicious about Bernadeta X.'s qualifications and filed a request with the court to oblige the witness to submit documents attesting to her qualifications. The Court admitted that evidence and obliged Bernadeta X. to submit the relevant documentation. The expert provided the court with 12 different documents which were supposed to certify her special knowledge, enabling her to give opinions on sexual offences. Unfortunately, most of the presented documents did not certify that she held the qualifications required to prepare opinions in this field. One of the documents was the decision issued by the President of the Regional Court in Olsztyn, by virtue of which Bernadeta X. was appointed a court expert in the field of sexual offences. As the President provided in the reasoning, the applicant had the appropriate qualifications and experience. None of the documents proved that she had received a higher education, although the President of the Regional Court pointed out that the expert demonstrated her higher education background, as she had completed extramural studies in librarianship and scientific information. That was a background completely unrelated to the opinion-giving area. The other two documents which were to confirm Bernadeta X.'s qualification (certificate of completion of a course for expert candidates, and a diploma confirming participation in the course entitled "Diagnosis and therapy of victims of sexual violence in the work of a court expert") were issued by the same institution. According to the list of the provided classes, only 10 hours were devoted to "Judicial diagnosis of victims and perpetrators of violence". Verification of the other documents also aroused great doubts as to the nature of the woman's substantive preparedness. Before the woman was entered on the list of court experts, the President of the Regional Court had not even taken the trouble to check and verify 
the truthfulness and quality of the data contained in the documents submitted, which was not impossible, since the accused parties' attorney-at-law was able to check and verify certain elements in a relatively quick and easy manner.

However, the doubts regarding the documents could not be a sufficient basis to contest the court expert's reliability. Categorical conclusions were formulated on the basis of a number of reports from persons who had been harmed by Bernadeta $X .^{70}$ The analysis of the content of the sexual and psychological opinions prepared and presented to the court by Bernadeta $X$. was based on diagnostic methods which were by no means reflected in modern psychology and led to wrong conclusions. ${ }^{71}$ In consequence of this "pseudo-expert's" activities, untrue, groundless and unjust conclusions were drawn, which often resulted in family breakdowns or even slander of sexual violence against minors.

The above case of the court expert entered in the list of experts by the President of one of the Regional Courts in Poland perfectly shows the flaws of the system related to reliable verification and control of a certain person's skills. Bernadeta X.'s activities were not only unethical, but they also significantly undermined confidence in the competencies of an expert. ${ }^{72}$

\section{REFERENCES}

Dzierżanowska J., Studzińska J., Biegli w postepowaniu sądowym cywilnym i karnym. Praktyczne omówienie regulacji z orzecznictwem, Komentarze problemowe, Warszawa 2019.

Dzierżanowska J., Studzińska J., "Kryteria oceny dowodu z opinii biegłego w orzecznictwie sadów powszechnych i Sądu Najwyższego", Roczniki Nauk Prawnych 25, 2015, no. 2.

Filewicz A., "ENFSI a perspektywy rozwoju kryminalistyki. Rola i znaczenie organizacji na arenie międzynarodowej”, Problemy Kryminalistyki 240, 2003.

Flaga-Gieruszyńska K., Biegły w postępowaniu cywilnym i karnym. Komentarz praktyczny z orzecznictwem. Wzory pism procesowych i orzeczeń, Warszawa 2018.

Girdwoyń P., Opinia biegłego w sprawach karnych europejskim systemie prawnym. Perspektywy harmonizacji, Warszawa 2011.

Grabowska B., Pietryka A., Wolny M., Bodnar A., Biegli sądowi w Polsce. Raport Helsińskiej Fundacji Praw Czlowieka, Warszawa 2014.

Grześkowiak A., Wiak K., “Art. 233”, [in:] Kodeks Karny. Komentarz, Legalis, Warszawa 2019.

Justice and Home Affairs Council, Brussels 13.12.2011, http://www.consilium.europa.eu.

Kompetencje biegłych sądowych — oczekiwania i kryteria oceny, przegląd rozwiazań stosowanych

70 Assistance was provided by the association called "Stop Manipulacji" [Stop Manipulation], which monitors the reliability of experts in psychology, sexology, psychiatry.

${ }^{71}$ B. Lewandowski, "Jakość weryfikowania kompetencji i rzetelności biegłych sadowych w Polsce. Studium przypadku”, [in:] Pozycja i rola biegłego w Polskim systemie prawnym, Warszawa 2016, pp. 153-154, 158, 166.

${ }_{72}$ Due to difficulties in reaching all the proceedings in which the said expert has drafted opinions, it is not possible to identify and determine how many of the opinions presented by her resulted in a conviction of defendants and what was the substantive value of the opinions submitted. 
w różnych państwach i systemach prawnych, Forensic Watch Project (no. E2/2162), http:// forensicwatch.pl/

Lewandowski B., "Jakość weryfikowania kompetencji i rzetelności biegłych sadowych w Polsce. Studium przypadku", [in:] Pozycja i rola biegłego w Polskim systemie prawnym, ed. B. Lewandowski, Warszawa 2016.

Nowak M., "Wątpliwości związane z odpowiedzialnością prawną biegłego sądowego w świetle znowelizowanego art. 233 § 4A Kodeksu Karnego", Zeszyty Prawnicze 17.2, 2017.

Pękała M., Rybicki P., "Elementy systemu oceny zgodności i ich przydatności do oceny kompetencji biegłych sądowych, [in:] Pozycja i rola biegłego w Polskim systemie prawnym, ed. B. Lewandowski, Warszawa 2016.

Stefański R., “Art. 233”, [in:] Kodeks Karny. Komentarz, Legalis, Warszawa 2018.

Tomaszewski T., Dowód z opinii biegłego w postępowaniu karnym, Kraków 2000.

Żelek P., Odpowiedzialność prawna biegłych sądowych? Czy bycie biegłym jest ryzykowne?, http:// katalizatortechnologii.pl/odpowiedzialnosc-prawna-bieglych-sadowych-czy-bycie-bieglym-jest-ryzykowne/ 